\title{
Sustainable management approach for sucking pests control in betel leaf of Bangladesh
}

\author{
Md. Motaher Hossain ${ }^{1}$, Ashutus Singha ${ }^{2}$, Md. Abu Sayem Jiku ${ }^{3 *}$ (D), Debasish Sarker ${ }^{4}$, Akhtaruzzaman Sarkar ${ }^{4}$, \\ Ashraful Alam ${ }^{5}$ and Shata Rupa Sinha ${ }^{6}$
}

\begin{abstract}
Background: Betel leaf is the oldest and now highly paid farmer's crop, but the most vulnerable to insect pests, leading to massive yield drops in Bangladesh. For this reason, the experiment was carried out at the Spices Research Centre, Bangladesh, during the period of January 2018 to December 2018 and to assess the effectiveness of the different bio-rational approach against the betel leaf sucking pests. In this study, BARI Paan-3 was used as a test crop. Studies were important that sucking insect pests to include red mite population (black fly, white fly, red mite and mealy bug) has been found actively around the year in Bangladesh.

Results: Studies have shown that sucking insect population (black fly, white fly, red mite and mealy bug) has been found actively year round, whereas the maximum (22.7, 17.2, 16.1, and 14 adult/vine) and minimum (3.2, 2.8, 2.6, and 1.5 adult/vine) were recorded during the month of October and January, respectively. The results explored that the significant variations and the $R^{2}$ value suggested that biotic factor contributes $57.9,50.9,51.3$, and $53.7 \%$ variations in black fly, white fly, red spider mite, and mealy bug population. Among approaches, the highest mortality rate (80.56, $84.73,82.44$, and $90.96 \%)$ of black fly, white fly, red mite, and mealy bug over untreated control with maximum vine yield (18.61 t/ha) is recorded from sanitation + three alternate spraying of fizimite and antario.

Conclusions: It had concluded that sanitation of betel leaf garden along with three alternate spraying of fizimite (sodium lauryl ether) at $1 \mathrm{ml} / \mathrm{l}$ and antario WP (Bt + abamectin $0.1 \%$ ) at $0.5 \mathrm{~g} / \mathrm{l}$ recommended for an effective management of the betel vine sucking pest complex.
\end{abstract}

Keywords: Betel leaf, Bio-rational, Strategy, Sucking pest

\section{Introduction}

Betel vine (Piper betle L.) is a perennial evergreen shade loving creeper belonging to the family Piperaceae. It is a highly remunerative crop to the farmers of Bangladesh. Betel vine is commercially cultivated in the moist, tropical, and sub-tropical regions of Bangladesh, India, and Sri Lanka and to a limited extent in some other Asian countries (Maiti and Saikia 2002). It plays a vital role in agriculture as well as in the economy of Bangladesh. It is

\footnotetext{
* Correspondence: jikuly@gmail.com

${ }^{3}$ Institute of Environmental and Sustainable development in Agriculture, Graduate school of Chinese Academy of Agricultural Science, Beijing, China Full list of author information is available at the end of the article
}

highly labor-intensive and one-hectare betel vine that can generate 5000 working days in a year (Acharjee et al. 1988). The vine cultivated traditionally over the years without any improved package of practices (Guha 2006). It is known that the extract of betel leaves has antioxidant property due to the presence of chevibetol (CHV), allylpyrocatechol (APC), (Choudhary and Kale 2002; Rathee et al. 2006), anti-carcinogenic properties due to the presence of hydroxyl-chavicol (Amonkar et al. 1986; Bhide et al. 1991) and also has hypolipidemic activity (Gramza and Korczak 2005) and antibacterial activity (Nalina and Rahim 2007; Bissa et al. 2007; Ramji et al. 2002). Researches in the recent past explore the 
scientific basis of the traditional uses of this plant as well as discovering new molecules in betel vine, which can be used as medicine. The crop is subjected to attack by large no. of insect pests causing huge loss in leaf yield (Nikam et al. 1958). The white and black fly, red mite, and mealy bug have been identified as the significant constraints in increasing the leaf yield of betel vine (Giri 1995; Jana 2006). To get rid of their infestation, farmers used to apply a minimum of 5 to 6 times of pesticide sprays, and the number of sprays are increasing over the years, and hence, the cost of cultivation has increased enormously making cultivation of betel leaf highly risky and non-profitable. This results in abatement in the biodiversity of natural enemies' vis-a-vis outbreak of secondary pests. In the recent past, the development of resistance to pesticides, pesticide-induced resurgence, and contamination of food and eco-system are problems incurred due to pesticide management. Pesticide residues in betel leaf are also of great concern from the point of domestic consumption and exports as well. Chemical insecticide results in the destruction of beneficial organisms, flora, and fauna. Cost-effective crop production requires a combination of optimum use of chemical and non-chemical techniques of pest management. Bio-rational management approach in recent years has gained importance in overcoming these problems. However, there are no studies done in Bangladesh on population buildup and management of sucking insects through the bio-rational approach. This study is therefore undertaken to study the population buildup of sucking insects as influenced by climatic factors and to evaluate the efficacy of different bio-rational-based management approaches against sucking insect pest complex of betel leaf.

\section{Materials and method}

The field study was conducted in 7 years old standing betel vine boroj at Spices Research Centre, BARI, Shibganj, Bogura, Bangladesh (geographic coordinates $25.0167^{\circ} \mathrm{N}, 89.3167^{\circ} \mathrm{E}$ ), during January 2018-December 2018 to study the population buildup of sucking insect pests as influenced by climatic factors and to evaluate the efficacy of different bio-rational-based management approaches against sucking insect pests complex of betel leaf. The experimental plot was prepared with five ploughings and cross ploughings followed by laddering to break the clods as well as to level the soil. The weeds and stubbles of previous crops were collected and removed from the soil. The unit plot size was $6 \mathrm{~m} \times 5 \mathrm{~m}$, and the spacing was $50 \mathrm{~cm} \times 25 \mathrm{~cm}$. BARI Paan- 3 was used as a test crop for this trial. The treatments were:

$T_{1}=$ sanitation + alternate spraying of spinosad (Success $2.5 \mathrm{SC}$ ) at $1.2 \mathrm{ml} / 1$ and abamectin (Biomax $1.8 \mathrm{EC}$ ) at $1 \mathrm{ml} / \mathrm{l}$
$T_{2}=$ sanitation + alternate spraying of azadirachtin (Bioneem plus1EC) at $1 \mathrm{ml} / \mathrm{l}$ and antario WP (Bt + abamectin $0.1 \%$ ) at $0.5 \mathrm{~g} / \mathrm{l}$

$T_{3}=$ sanitation + alternate spraying of abamectin (Bio$\max 1.8 \mathrm{EC}$ ) at $1 \mathrm{ml} / \mathrm{l}$ and fytoclean (potassium salt of fatty acid) at $5 \mathrm{ml} / \mathrm{l}$

$T_{4}=$ sanitation + alternate spraying of fizimite (sodium lauryl ether) at $1 \mathrm{ml} / \mathrm{l}$ and antario wp ( $\mathrm{Bt}+$ abamectin $0.1 \%)$ at $0.5 \mathrm{~g} / \mathrm{l}$

$T_{5}=$ farmers practice: spraying of imidacloprid (Admire 200SL) at $0.25 \mathrm{ml} / \mathrm{l}$

$T_{6}=$ untreated control.

Treatments were assigned in a randomized complete block design with three replications. Recommended doses of fertilizers (MOC $6 \mathrm{t} / \mathrm{ha}$, urea $180 \mathrm{~kg}$, TSP 150 $\mathrm{kg}$, MoP $36 \mathrm{~kg}$, Zypsum $50 \mathrm{~kg}$, and zinc sulphate $15 \mathrm{~kg}$ per hectare) were applied. To control anthracnose of betel leaf, the crop was sprayed with Tilt 250EC at 0.5 $\mathrm{ml} / \mathrm{L}$ of water at 15 days interval starting from the month of March to May. For the control of leaf rot or vine rot disease, three alternate sprays of Ridomil MZ 72 WP $(0.2 \%)$, Secure $(0.1 \%)$, and Score $(0.1 \%)$ were done at 10 days interval. For counting the population of black fly, white fly, red mite, and mealy bug, ten rows from the middle of the boroj were chosen. Two vines were taken randomly from each row, totaling 20 vines from ten rows. Adult white and black flies, red mite, and mealy bug populations were recorded at monthly intervals during January 2018-December 2018 for seasonal incidence of those sucking pests. Three sprays were given at 15 days interval during the Month of March-April and August-September. In each plot, ten betel vines were visually checked to count pest populations and to measure the number of pest per vine. The yield of fresh betel vine from different plucking was revealed from each treated plots and computed as $\mathrm{t}$ ha $-{ }^{1}$. The recorded data were analyzed, and mean values were adjusted and separated by Duncan's Multiple Range Test (DMRT) according to Gomez and Gomez (1984). Percent of black fly, white fly, red mite, and mealy bug population reduction over untreated control was calculated using the following formula of Dutta et al. (2014).

Insect population reduction $(\%)$
$=\frac{\text { Mean value of control-Mean value of treatments }}{\text { Mean value of controls }} \times 100$

\section{Results}

Incidence of betel vine insect pests with weather parameters is presented in Table 1, and monthly distribution of meteorological parameters and insect population buildup in betel leaf is presented in Fig. 1.

White fly inhabitants ranged from 2.8 to 17.2 and reached its peak of 16.8/vine during May and 17.2 
Table 1 Monthly distribution of meteorological parameters and insect population buildup in betel leaf during January to December 2018

\begin{tabular}{|c|c|c|c|c|c|c|c|}
\hline \multirow{2}{*}{$\begin{array}{l}\text { Observation } \\
\text { Month }\end{array}$} & \multirow{2}{*}{$\begin{array}{l}\text { Average } \\
\text { temperature }\left({ }^{\circ} \mathrm{C}\right)\end{array}$} & \multirow{2}{*}{$\begin{array}{l}\text { Relative } \\
\text { humidity (\%) }\end{array}$} & \multirow{2}{*}{$\begin{array}{l}\text { Average } \\
\text { rainfall (mm) }\end{array}$} & \multicolumn{4}{|c|}{ Mean no. of insect population/vine } \\
\hline & & & & Black fly & White fly & Red mite & Mealy bug \\
\hline January 2018 & 18.1 & 81.5 & 9 & 3.2 & 2.8 & 2.6 & 1.5 \\
\hline February 2018 & 22.5 & 78.7 & 0 & 5.6 & 4.8 & 4.6 & 3.5 \\
\hline March 2018 & 26.6 & 76.3 & 0 & 8.3 & 7.4 & 7.1 & 6.0 \\
\hline April 2018 & 30.4 & 75.9 & 0 & 15.8 & 12.9 & 11.9 & 10.7 \\
\hline May 2018 & 31.2 & 74.5 & 127 & 20.5 & 16.8 & 15.8 & 13.7 \\
\hline June 2018 & 29.8 & 85.5 & 430 & 15.2 & 11.7 & 10.7 & 9.6 \\
\hline July 2018 & 29.6 & 85.1 & 550 & 12.2 & 6.6 & 6.4 & 5.3 \\
\hline August 2018 & 29.3 & 87.9 & 292 & 10.5 & 2.5 & 2.3 & 1.2 \\
\hline September 2018 & 28.8 & 84.3 & 208 & 12.2 & 9.3 & 8.3 & 7.2 \\
\hline October 2018 & 28.1 & 81.4 & 198 & 22.7 & 17.2 & 16.1 & 14 \\
\hline November 2018 & 25.6 & 81.6 & 0 & 18.2 & 14.3 & 13.3 & 11.2 \\
\hline December 2018 & 19.9 & 83.2 & 0 & 4.6 & 3.6 & 3.4 & 2.3 \\
\hline
\end{tabular}

Source: Meteorological station, Bogra

during October. Red mite population ranged from 2.6 to 16.1 and reached its peak 15.8/vine during May and 16.1 during October. Present results were in concurrence with the findings of Roopa and Nandihalli (2009) and Nandini et al. (2010). The incidence of mealy bug was started from the first week of January and continued till to the complete growing period of betel vine plant. Population ranged from 1.5 to 14.0 and reached its peak 13.6/vine during May and 14.0 during October. Multiple linear regression models, along with coefficients of determination $\left(R^{2}\right)$ regarding the impact of weather parameters on the seasonal abundance of different insect pest of betel leaf, are presented in Table 2 .

It was evident from Table 2 that temperature individually contributed $54.7 \%$ abundance of black fly population buildup, and its effect was significant. The combined effect of temperature and relative humidity was significant and exerted $57 \%$ abundance. The average monthly rainfall along with temperature and relative humidity contributed $57.9 \%$ abundance of black

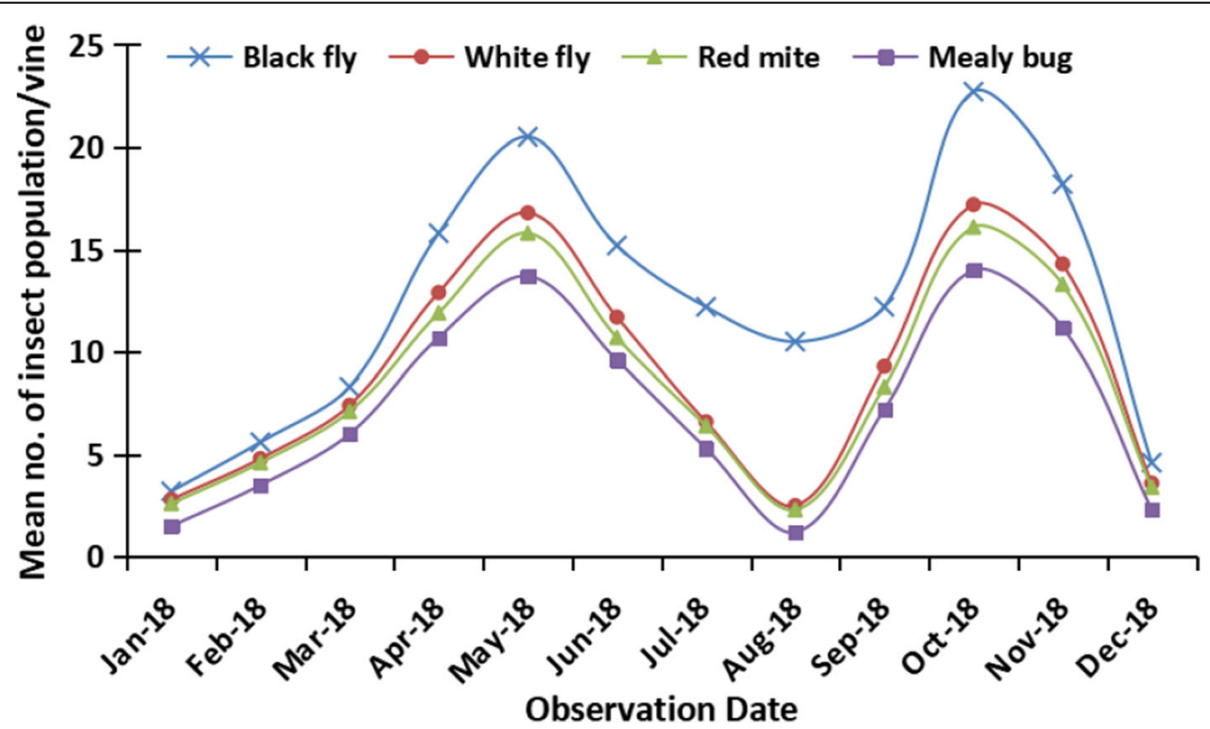

Fig. 1 Mean number of insect population per vine observed at different date in Betel leaf. It was evident from the study that black fly population incidence was started from the month of January (3.2 adult/vine) and continued until the entire growing period of the crop. Population ranged from 3.2 to 22.7 and reached its peak 20.5/vine and 22.7/vine during the month of May and October, respectively 
Table 2 Multiple linear regression models along with coefficients of determination $\left(R^{2}\right)$ regarding the impact of weather parameters on the seasonal abundance of different insect pests of betel leaf

\begin{tabular}{|c|c|c|c|c|c|}
\hline Name of the insect & Regression equation & $R^{2}$ & $100 R^{2}$ & $\%$ Role of individual factor & F statistic \\
\hline \multirow[t]{3}{*}{ Black fly } & $Y=-16.438+1.082 X_{1}$ & 0.547 & 54.7 & 54.7 & $F_{1,10}=12.09, P<0.01$ \\
\hline & $Y=2.190+1.075 X_{1}-0.227 X_{2}$ & 0.570 & 57.0 & 3.7 & $F_{2,9}=5.97, P<0.05$ \\
\hline & $Y=-14.675+1.222 X_{1}-0.057 X_{2}-0.006 X_{3}$ & 0.579 & 57.9 & 0.9 & $F_{3,8}=3.67, P<0.10$ \\
\hline \multirow[t]{3}{*}{ White fly } & $Y=-12.201+0.726 X_{1}$ & 0.343 & 34.3 & 34.3 & $F_{1,10}=5.21, P<0.05$ \\
\hline & $Y=31.610+0.710 X_{1}-0.509 X_{2}$ & 0.503 & 50.3 & 16.0 & $F_{2,9}=4.56, P<0.05$ \\
\hline & $Y=20.288+0.809 X_{1}-0.395 X_{2}-0.004 X_{3}$ & 0.509 & 50.9 & 0.6 & $F_{3,8}=2.76, P<0.10$ \\
\hline \multirow[t]{3}{*}{ Red spider mite } & $Y=-9.342+0.671 X_{1}$ & 0.339 & 33.9 & 33.9 & $F_{1,10}=5.12, P<0.05$ \\
\hline & $Y=30.813+0.655 X_{1}-0.489 X_{2}$ & 0.510 & 51.0 & 17.1 & $F_{2,9}=4.69, P<0.05$ \\
\hline & $Y=2.843+0.725 X_{1}-0.408 X_{2}-0.003 X_{3}$ & 0.513 & 51.3 & 0.3 & $F_{3,8}=2.82, P<0.10$ \\
\hline \multirow[t]{3}{*}{ Mealy bug } & $Y=-10.008+0.645 X_{1}$ & 0.363 & 36.3 & 36.3 & $F_{1,10}=5.70, P<0.05$ \\
\hline & $Y=27.265+0.630 X_{1}-0.454 X_{2}$ & 0.535 & 53.5 & 17.2 & $F_{2,9}=5.18, P<0.05$ \\
\hline & $Y=1.223+0.683 X_{1}-0.393 X_{2}-0.002 X_{3}$ & 0.537 & 53.7 & 0.2 & $F_{3,8}=3.10, P=0.089$ \\
\hline
\end{tabular}

$Y=$ insect population/vine; $X_{1}=$ average temperature $\left({ }^{\circ} \mathrm{C}\right) ; X_{2}=$ relative humidity $(\%) ; X_{3}=$ average rainfall $(\mathrm{mm})$

fly population which was statistically significant. The individual effect of relative humidity and rainfall on black fly population abundance was $3.7 \%$ and $0.9 \%$, respectively. However, in the case of white fly abundance, temperature individually contributed $34.3 \%$ abundance, and its effect was significant. The combined effect of temperature and relative humidity was significant and exerted $50.3 \%$ abundance. The average monthly rainfall along with temperature and relative humidity contributed $50.9 \%$ abundance of white fly population which was statistically significant. The individual effect of relative humidity and rainfall on white fly population abundance was $16 \%$ and $0.6 \%$, respectively. In the case of red spider mite abundance, temperature individually contributed $33.9 \%$ abundance and its effect was significant. The combined effect of temperature and relative humidity was significant and exerted $51 \%$ abundance. The average monthly rainfall along with temperature and relative humidity contributed 51.3\% abundance of red mite population that was statistically significant. The individual effect of relative humidity and rainfall on red mite population abundance was $17.1 \%$ and $0.3 \%$, respectively. The combined effect of temperature and relative humidity was significant and exerted $53.5 \%$ abundance. The average monthly rainfall along with temperature and relative humidity contributed $53.7 \%$ abundance of mealy bug population. The individual effect of relative humidity and rainfall on mealy bug population abundance was $17.2 \%$ and $0.3 \%$, respectively. The multiple linear regression analysis showed that all the weather parameters together contributed $53.7 \%$ population abundance of mealy bug, and the equation was not significant.

\section{Efficacy of different treatments against sucking pests of betel leaf}

Efficacy of different treatments against sucking pests of betel leaf is presented in Table 3.

Table 3 Efficacy of different treatments against sucking pests of betel leaf (mean of three sprayings)

\begin{tabular}{|c|c|c|c|c|c|c|c|c|}
\hline Treatments & $\begin{array}{l}\text { No. of black } \\
\text { fly/vine }\end{array}$ & $\begin{array}{l}\text { \% reduction } \\
\text { over control }\end{array}$ & $\begin{array}{l}\text { No. of white } \\
\text { fly/vine }\end{array}$ & $\begin{array}{l}\% \text { reduction } \\
\text { over control }\end{array}$ & $\begin{array}{l}\text { No. of red } \\
\text { mite /vine }\end{array}$ & $\begin{array}{l}\text { \% reduction } \\
\text { over control }\end{array}$ & $\begin{array}{l}\text { No. of mealy } \\
\text { bug / vine }\end{array}$ & $\begin{array}{l}\text { \% reduction } \\
\text { over control }\end{array}$ \\
\hline Sanitation + spinosad + abamectin & $3.51 d$ & 78.06 & 2.23de & 74.40 & $1.92 \mathrm{~cd}$ & 73.66 & $0.91 d$ & 87.15 \\
\hline Sanitation + azadirachtin + antario & $7.55 c$ & 52.81 & $3.60 \mathrm{c}$ & 58.67 & $3.11 \mathrm{c}$ & 57.34 & $3.92 b$ & 44.63 \\
\hline Sanitation + abamectin + fytoclean & $11.43 b$ & 28.56 & $4.92 b$ & 43.51 & $5.14 b$ & 29.49 & $1.75 \mathrm{~cd}$ & 75.28 \\
\hline Sanitation + fizimite + antario & $3.11 d$ & 80.56 & $1.33 e$ & 84.73 & $1.28 d$ & 82.44 & $0.64 d$ & 90.96 \\
\hline Farmers practice & $6.86 c$ & 57.13 & $2.95 \mathrm{~cd}$ & 66.13 & $2.97 \mathrm{~cd}$ & 59.26 & $2.60 \mathrm{c}$ & 63.28 \\
\hline Untreated control & $16.00 a$ & - & $8.71 a$ & - & $7.29 a$ & - & $7.08 a$ & - \\
\hline Level of sigf. & $* *$ & - & $* *$ & - & $* *$ & - & $* *$ & - \\
\hline CV (\%) & 6.95 & & 10.10 & - & 17.63 & - & 16.43 & - \\
\hline
\end{tabular}


Among the different treatments tested, black fly population was ranged from 3.11 to 16 adult/vine. The treatment sanitation with three alternate spraying of fizimite and antario recorded significantly the lowest number of black fly (3.11adult/vine) population which was statistically similar with sanitation with three alternate spraying of spinosad and abamectin treated plot with black fly population of 3.51 adults/vine. The maximum number of black fly (16.00) was recorded from untreated control. However, the highest $(80.56 \%)$ reduction of black fly population over untreated control was calculated from sanitation with three alternate spraying of fizimite and antario-treated plot followed by sanitation with three alternate spraying of spinosad and abamectin and farmers practice with population reduction of $78.06 \%$ and $57.13 \%$, respectively. Among the different treatments, significantly, the lowest number of white fly (2.44 adult/ vine) was recorded in sanitation with three alternate spraying of fizimite and antario-treated plot which was statistically similar with sanitation with three alternate spraying of spinosad and abamectin with white fly population of 2.23 adults/vine. However, the maximum $(84.73 \%)$ reduction of white fly population over untreated control was recorded from sanitation with three alternate spraying of fizimite and antario-treated plot followed by sanitation with three alternate spraying of spinosad and abamectin and farmers practice with population reduction of $74.40 \%$ and $66.13 \%$, respectively. Similarly, the treatment sanitation with three alternate spraying of fizimite and antario recorded significantly the lowest number of red mite (1.28/vine) population which was statistically similar with sanitation with three alternate spraying of spinosad and abamectin-treated plot with mite population of $1.92 /$ vine. The maximum number of black fly (7.29/vine) was recorded from untreated control. However, the highest (82.44\%) reduction of black fly population over untreated control was calculated from sanitation with three alternate spraying of fizimite and antario-treated plot followed by sanitation with three alternate spraying of spinosad and abamectin and farmers practice with population reduction of $73.66 \%$ and $59.26 \%$, respectively. The maximum number of mealy bug population (7.08 adult/vine) was recorded from untreated control. Effect of different treatments on fresh vine yield of betel leaf is presented in Fig. 2.

The highest vine yield (18.61 t/ha) was also obtained from sanitation + alternate spraying of fizimite and antario followed by sanitation + alternate spraying of spinosad and abamectin ( $16.67 \mathrm{t} / \mathrm{ha})$ that indicated better control of sucking insect pest compared to other treatments. The lowest yield $(9.11 \mathrm{t} / \mathrm{ha})$ was recorded from the untreated control plot.

\section{Discussion}

The crop has been cultivated traditionally over the years without any improved package of practices leading to diminishing returns (Guha 2006). The crop was raised under covered structure creating a microclimatic condition that not only favors crop growth but also influences pest incidence. Jana (2006) reported two-peak population of black fly on betel vine once from May to August and other from September to November, which confirms the findings of the present study. However, white fly incidence was started from the first week of January and

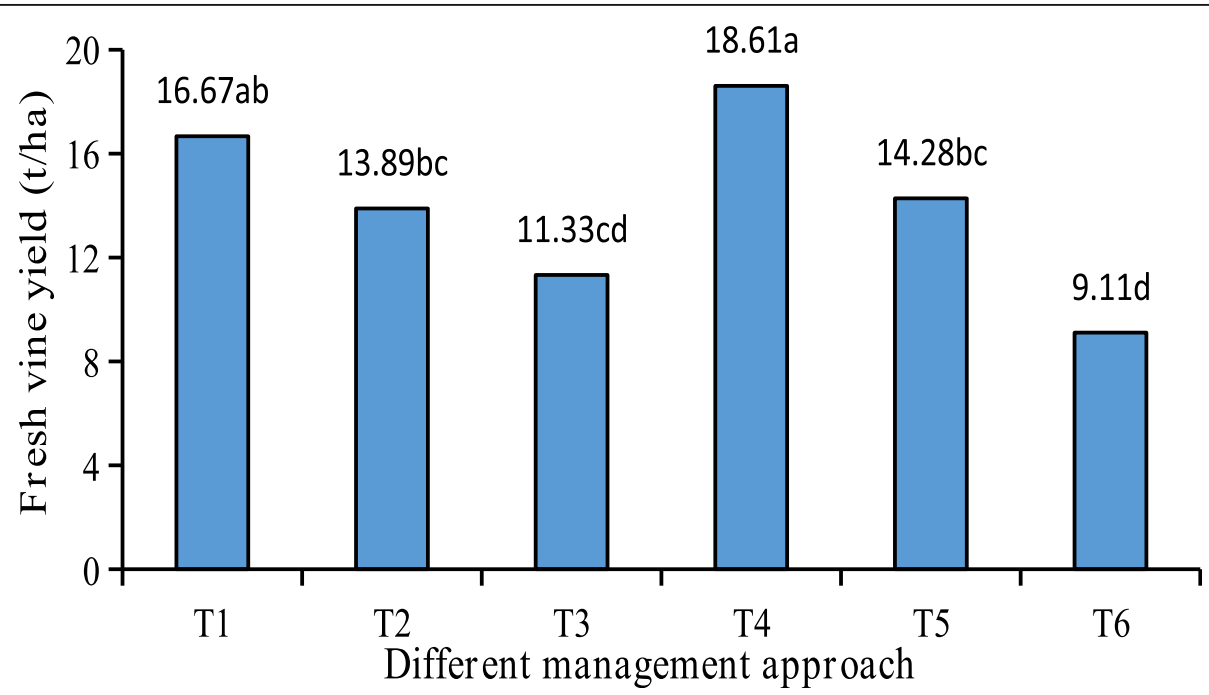

Fig. 2 Effect of different treatments on fresh vine yield of betel leaf. $T 1=$ sanitation + spinosad + abamectin, $T 2=$ sanitation + azadirachtin + antario, T3 = , anitation + abamectin + fytoclean, T4 = sanitation + fizimite + antario, T5 = farmers practice, and T6 = untreated control (water spray) 
continued till to the entire growing period of a betel vine plant. Giri (1995) observed that the highest population of white fly was found from October to November, which confirms the results under the present investigation. In the case of red mite, the incidence was started from January and continued until the entire growing period of betel vine plant. All the treatments except untreated control recorded a significantly lower number of sucker insect pest populations. However, different sucking pest treatment sanitation with three alternate spraying of fizimite and antario recorded significantly the lowest number (0.64/vine) of adult mealy bug population which was statistically similar with sanitation with three alternate spraying of spinosad and abamectin-treated plot with mite population of $0.91 /$ vine. However, the highest $(90.96 \%)$ reduction of mealy bug population over untreated control was calculated from sanitation with three alternate spraying of fizimite and antario followed by sanitation with three alternate spraying of spinosad and abamectin and sanitation with three alternate spraying of abamectin and fytoclean with a population reduction of $87.15 \%$ and $75.28 \%$, respectively. The multiple linear regression analysis showed that all the weather parameters together contributed $50.9 \%$ white fly, $51.3 \%$ red mite, $36.3 \%$ mealy bug, and $57.9 \%$ black fly population abundance, and the equation was significant. Mandal et al. (2008) reported 16.91 to $27.07 \%$ increase in yield of cotton over control due to the use of biopesticides. Cost-effective crop production requires a combination of optimum use of chemicals and non-chemical techniques of pest management specially for sucking types of insect pest.

\section{Conclusion}

From the study, it had been concluded that sanitation + alternate spraying with fizimite $(1 \mathrm{ml} / \mathrm{L}$ of water) and antario $(0.5 \mathrm{~g} / \mathrm{L}$ of water) three times at 10 days interval from the first appearance of insect infestation was recommended for the management of sucking insect pest complex of betel leaf with higher yield. Furthermore, management strategy add with farmer's attitude focuses for betel leaf cultivation.

\section{Acknowledgements}

The authors are thankful to the Spices Research Centre, BARI, for the provision of laboratory facilities to carry out this research. I would like to acknowledge the contributions of several of my colleagues who conducted research and coauthored articles with me on this topic over the years.

\section{Authors' contributions}

Conceptualization, methodology and investigation: [Md. Motaher Hossain]; Writing -original draft preparation: [Md. Motaher Hossain]; Formal analysis: [Md. Motaher Hossain, Ashutus Singha, and Md. Abu Sayem Jiku,],

Writing—review and editing: [Md. Motaher Hossain, Md Abu Sayem Jiku, Md. Akhtaruzzaman Sarkar, Ashutus Singha, Debasish Sarker, Md Ashraful Alam, and Shata Rupa Sinha]; Funding acquisition: [Md. Motaher Hossain, Md. Akhtaruzzaman Sarkar, and Debasish Sarker]; Supervision: [Debasish Sarker]. All authors revised, read, and approved the final manuscript.
Funding

There are currently no funding sources in the design of the study and collection, analysis, and interpretation of data and in writing the manuscript.

\section{Availability of data and materials}

The datasets generated and/or analyzed during the current study are included in this study.

Ethics approval and consent to participate

Not applicable

\section{Consent for publication}

Not applicable.

\section{Competing interests}

The authors declare that the research was conducted in the absence of any commercial or financial relations that could be constructed as a potential conflict of interest.

\section{Author details}

${ }^{1}$ Spices Research Centre, BARI, Shibganj, Bogura, Bangladesh. ${ }^{2}$ Irrigation and Water Management, Sylhet Agricultural University, Sylhet 3100, Bangladesh. ${ }^{3}$ Institute of Environmental and Sustainable development in Agriculture, Graduate school of Chinese Academy of Agricultural Science, Beijing, China. ${ }^{4}$ Bangladesh Agricultural Research Institute, Gazipur, Bangladesh. ${ }^{5}$ Institute of Agricultural Resources and Regional Planning, Graduate school of Chinese Academy of Agricultural Science, Beijing, China. ${ }^{6}$ Department of Horticulture, Bangladesh Agricultural University, Mymensingh, Bangladesh.

Received: 9 January 2020 Accepted: 26 March 2020

Published online: 10 April 2020

\section{References}

Acharjee S, Sengupta K, Samanta SK (1988) Economical aspects of betel vine cultivation in Midnapore district of W. B. Environ Ecol 6:444-445

Amonkar AJ, Nagabhushan MD, Suja AV, Bhide SV (1986) Hydroxychavicol: a new phenolic antimutagens from betel leaf. Food Chem Toxicol 24:1321-1324

Bhide SV, Zariwala MBA, Amonlar AJ, Azuine MA (1991) Chemo-preventive efficacy of betel leaf extract against benzo(a) pyrene induced fore-stomach tumors in mice. J Ethnopharmacol 34:207-213

Bissa S, Songara D and Bohra A (2007) Traditions in oral hygine chewing of betal (piper betal L.) leaves. Curr Sci 92:26-8.

Choudhary D, Kale RK (2002) Antioxidant and non-toxic properties of Piper betel leaf extract: in vitro and in vivo studies. Phytother Res 16(5):461-466

Dutta NK, Mahmudunnabi M, Begum K, Ferdous A, Alam SN. (2014). Development of a management approach against sucking pests of brinjal. Annual Report 2013-14, Entomology Division, BARI, Joydebpur, Gazipur-1701, pp. 23-24.

Giri S. (1995). The incidence pattern of two aleurodids during different months. M. Sc. Thesis Bidhan Chandra Krishi Viswavidyalaya, Mohanpur, Nadia, West Bengal.

Gomez KA, Gomez AA. (1984). Statistical Procedures for Agricultural Research. 2nd ed., Intl. Rice Res. Inst., John Willy and Sons, New York, Chichester, Brisbane, Toronto, Singapore, pp. 187-240.

Gramza A, Korczak J (2005) Tea constituents (Camellia sinensis L) as antioxidant in lipid systems. Trends Food Sci Technol 16:351-358

Guha P (2006) The Neglected green gold of India. J Hum Ecol 19:87-93

Jana BL. (2006). Betelvine-a traditional cash crop of rural India,Agro Tech Publishing Academy, Udaipur. pp. 159-63.

Maiti S, Saikia L. (2002). Genetic resources of netelvine inlndia,Technical Bulletin, AICRP on Betelvine, National Research Centre for Medicinal and Aromatic Plants, Anand, Gujarat, India,pp31.

Mandal S, Patel AM, Patel CC (2008) Efficacy of certain commercially available biopesticides against boll worm of cotton. Indian Journal of Applied Entomology 22(2):128-130

Nalina T, Rahim ZHA (2007) The crude aqueous extract of Piper betle L. and its antibacterial effect towards Streptococcus mutans. American Journal of Biotechnology and Biochemistry 3(1):10-15

Nandini GRS, Mantur SM, Patil K, Mallapur CP, Ashalatha KV (2010) Population dynamics and extent damage of pests of Capsicum under protected cultivation. Karnatak a Journal of Agricultural Sciences 25:150-151 
Nikam BG, Mahadik CN, Rathore VS (1958) Pan crop pests should not be left alone. Indian Farm 8:11-13

Ramji N, Iyer R, Chandrasekaran S (2002) Phenolic antibacterials from Piper betle in the prevention of halitosis. Journal of Ethnopharmarmacology 83(1-2):149-152

Rathee JS, Patro BS, Mula S, Gamre S, Chattopadhyay S (2006) Antioxidant activity of Piper betle extract and its constituents. J Agric Food Chem 54(24):9046-9054

Roopa SP, Nandihalli BS (2009) Seasonal incidence of mite pests on brinjal and chilli. Karnataka Journal of Agricultural Sciences 22(3):729-731

\section{Publisher's Note}

Springer Nature remains neutral with regard to jurisdictional claims in published maps and institutional affiliations.

\section{Submit your manuscript to a SpringerOpen ${ }^{\circ}$ journal and benefit from:}

- Convenient online submission

- Rigorous peer review

- Open access: articles freely available online

High visibility within the field

- Retaining the copyright to your article

Submit your next manuscript at $\boldsymbol{\nabla}$ springeropen.com 